\title{
レーザー溶融反応によるチタンのアルそナイジングと その耐酸化性
}

\author{
新谷昌宣*, 竹本幹男** \\ $*$ 青山学院大学理工学部大学院 \\ ** 青山学院大学理工学部
}

\author{
Aluminizing of Titanium by Laser Fusion Reaction and Oxidation \\ Resistance of the Coatings \\ Masanobu Shinya* and Mikio Takemoto** \\ * Graduate School, Aoyama Gakuin University \\ ** Faculty of Science and Engineering, Aoyama Gakuin University
}

\begin{abstract}
In order to produce aluminide coatings with an excellent oxidation resistance, aluminizing of titanium substrate was conducted utilizing a high power infrared laser fusion reaction. Titanium substrate painted with aluminum powder was laser fused in argon gas atmosphere. Three types of titanium aluminide coatings of $150 \mu \mathrm{m}$ thickness, i.e., single phase of $\mathrm{Ti}_{3} \mathrm{Al}$, TiAl and composite phase of $\mathrm{TiAl}_{3}+\mathrm{Al}$, could easily be produced with a high reproducibility. The chemical composition of these coatings could be controlled by choosing both the laser irradiation conditions and the amount of painted aluminum powder. Corrosion resistance of these coatings was evaluated at 1073,1173 and $1273 \mathrm{~K}$ in the stagnant air. Changes of the composition and the stracture of the laser produced coatings during oxidation were carefully examined by SEM-EPMA and micro-area X-ray diffraction every 6 hours. The $\mathrm{Ti}_{3} \mathrm{Al}$ coating was slightly oxidized already at $1073 \mathrm{~K}$ according to a parabolic law. The TiAl coating was highly resistant to oxidation at $1073 \mathrm{~K}$, however, was oxidized at temperatures above $1173 \mathrm{~K}$. On the contrary, the composite coating of $\mathrm{TiAl}_{3}+\mathrm{Al}$ showed an excellent performance against high temperature oxidation even at $1273 \mathrm{~K}$. Aluminum in this composite coating was oxidized during early short exposure and produced alumina of $160 \mu \mathrm{m}$ thickness which contributed as a diffusion barrier of oxygen. The high oxidation resistance of this coating was due to the formation of alumina by the oxidation of $\mathrm{Al}$ and also to the thermal diffusion of $\mathrm{Al}$ into the titanium substrate, resulting in a protective thick $\mathrm{TiAl}_{3}$ layer.
\end{abstract}

Key words: intermetallic compound, titanium aluminide, oxidation resistance, infrared laser, beam scanner, surface modification, aluminizing, coating

\section{1. 緒言}

チタンーアルミニウム 2 元系金属間化合物 (以下, $\mathrm{Ti}_{x}$ $\mathrm{Al}_{y}$ ) は軽量耐熱材料として注目され，特に $\mathrm{TiAl}, \mathrm{TiAl}_{3}$ は航空機用ガスタービンブレード, 自動車用ターボチャ ージャーロータ, 将来は宇宙往還機構造部材などへの適 用が考学られ, 精力的に研究されている。 $\mathrm{Ti}_{x} \mathrm{Al}_{y}$ の厳密 な組成比の制御はかなり難しいが，一般にその高温強度 は負の温度依存性を持つこと采, 高温酸化中に $\mathrm{Al}_{2} \mathrm{O}_{3}$ /

*,** 干157 東京都世田谷区千歳台 6-16-1 (6-16-1, Chitosedai, Setagaya-ku, Tokyo, 157 Japan)
$\mathrm{TiO}_{2}$ 層を形成し, 緻密な $\mathrm{Al}_{2} \mathrm{O}_{3}$ 層が形成されれば優れ た耐高温酸化性を示すことなどが報告されている2，3。 例えば, 武井ら ${ }^{4), 5)}$ は, $\mathrm{TiAl}$ 及び純 $\mathrm{Ti}$ に $\mathrm{Al}$ 拡散浸透 処理を行い，耐高温酸化性の改善を試みた。表面に $\mathrm{TiAl}_{3}$ 層が生成されれば, $1100^{\circ} \mathrm{C}$ でも十分な耐酸化性を維持 するものの, 拡散浸透処理層中に割れが発生しやすく, 局所的酸化が進行するといら欠点があることを報告して いる。吉原ら ${ }^{2)}$ と小林らは ${ }^{3)}$ は, TiAl の低酸素分圧下の 熱処理によって, 表層に平衡解離圧の低い緻密な $\mathrm{Al}_{2} \mathrm{O}_{3}$ 層を選択酸化させて作ることを試みた。この処理を受け 
Table 1 Laser irradiation conditions for laser fusion reaction.

\begin{tabular}{|c|c|}
\hline Beam diameter & $0.41 \mathrm{~mm}\left(\right.$ TEM $_{01}$ Doughnut Mode $)$ \\
\hline Spot diameter: $\mathrm{D}$ & $0.407 \sim 0.976 \mathrm{~mm}$ \\
\hline Laser power: $\mathrm{P}$ & $100 \sim 1000 \mathrm{~W}$ \\
\hline Oscillating frequency: $\mathrm{F}$ & $4.4 \mathrm{~Hz}$ \\
\hline Table velocity: $\mathrm{V}_{\mathrm{t}}$ & $0.02 \sim 0.1 \mathrm{~m} / \mathrm{min}$ \\
\hline Power density: $\mathrm{P}_{\mathrm{d}}$ & $1.34 \times 10^{4} \sim 7.70 \times 10^{5} \mathrm{~W} / \mathrm{cm}^{2}$ \\
\hline Irradiation time: $\mathrm{t}_{\mathrm{d}}$ & $4.52 \times 10^{-3} \sim 1.09 \times 10^{-2} \mathrm{sec}$ \\
\hline Specific energy: $\mathrm{E}_{\mathrm{s}}$ & $1.45 \times 10^{2} \sim 3.48 \times 10^{3} \mathrm{~J} / \mathrm{cm}^{2}$ \\
\hline
\end{tabular}

た TiAl の耐酸化性は, $900^{\circ} \mathrm{C}$ までは良好であるが, 生 成された $\mathrm{Al}_{2} \mathrm{O}_{3}$ 層が薄いため, $950^{\circ} \mathrm{C}$ 以上では酸化増量 が急激に大きくなると報告している。耐酸化性を改善す るため,これまで種々の表面処理法が活発になされてい るものの,どれも一長一短を持ち合わせている。この種 の金属間化合物を実用化するためには，常温鞎性を改善 することも極めて大事である。このため，マイクロアロ イングによる靯性の付与についての研究も活発に行わ れ, TiAl では 3\% \%) の常温延性を得るまでになり, $\mathrm{TiAl}_{3}$ に执いても第 3 元素添加による延性改善の兆しが認めら れている゙。

一方, 著者らは, 表面处理法の一つとして赤外レーザ 一溶融反応による傾斜濃度セラミック/金属複合層のコ ーティング8 〜10)などを行ってきた。目的とする耐環境強 度を付与するためには, それぞれに固有のレーザー処理 技術が必要であるものの, しかるべき方法を用いれば実 用化できることも明らかにした。金属間化合物の中でも 耐高温酸化性に優れている $\mathrm{Al}_{3} \mathrm{X}$ 型は, その常温靱性の 低さから, 単体としての利用よりコーティング層として の応用が先行するものと考兄られる。比較的簡単な雾囲 気制御下で高速厚膜コーティングのできるレーザー溶融 反応技術は, 最も可能性のあるコーティング技術になり 得る。本報では, 純 $\mathrm{Ti}$ 上に塗布した $\mathrm{Al}$ 粉末の炭酸ガ スレーザー溶融反応で創成した $\mathrm{Ti}_{3} \mathrm{Al}$, $\mathrm{TiAl}$ 単相, 及び $\mathrm{TiAl}_{3}+\mathrm{Al}$ 複合コーティング層の耐酸化性について検討 した結果を報告する。

\section{2. 実験方法}

基板には， $20^{\mathrm{W}} \times 18^{\mathrm{L}} \times 3^{\mathrm{T}} \mathrm{mm}$ の純チタン板をエメり 一（\#600）研磨後，アセトン脱脂して用いた。この基板 上にアセトン希釈ビニル樹脂系接着剤と $\mathrm{Al}$ 粉末 (純度： 99.99\%)のペースト (Al 濃度: 75 wt\%) を 0.08〜0.46 g/ $\mathrm{cm}^{2}$ に塗布し, 自然乾燥させた。この試験片を Fig. 1 K 示すアルゴンガス雾囲気制御チャンバー内で, 前報8),10)

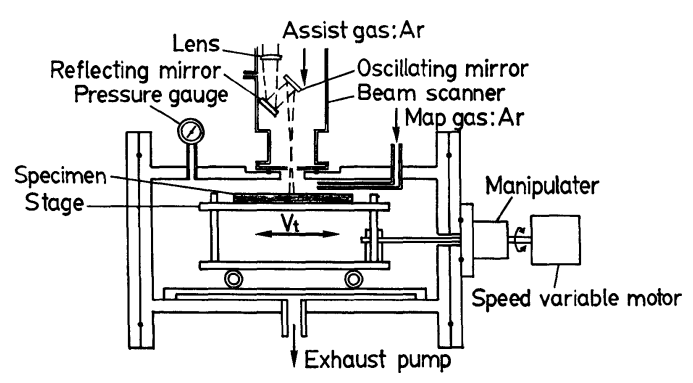

Fg. 1 Schematic illustration of the experimental apparatus for the laser fusion reaction.

に示したビームスキャニング法を用いたレーザー照射を 行った。試験片は, $4 \mathrm{~Hz}$ で振動するビームと直交方向に 速度 $V_{\mathrm{t}}$ で移動させ, $8 \mathrm{~mm}$ 幅の帯状溶融反応処理を行 った。レーザーは最高出力： $2.5 \mathrm{~kW}$ の炭酸ガスレーザ ーをマルチモード ( $\mathrm{TEM}_{01}$, ドーナツ型パワー分布), 連 続波で使用した。Table 1 には, 今回の実験で行った具 体的なレーザー処理条件を示す。本報の実験は，均一な コーティング層の得られるレーザー投入エネルギー： $E_{\mathrm{S}}$ $=2780 \mathrm{~J} / \mathrm{cm}^{2}$ (レーザーパワー: $P=800 \mathrm{~W}$ ，テーブル送 り速度: $\left.V_{\mathrm{t}}=0.054 \mathrm{~m} / \mathrm{min}\right)$, オーバーラップ回数: $N=3$ に固定した。なお，レーザー処理条件関するパラメー ターの詳細は, 前報 ${ }^{10)}$ に記載した通りである。

試作した $\mathrm{Ti}_{x} \mathrm{Al}_{y}$ コーティング層の高温酸化試験は, 静止大気中 $1073 \mathrm{~K}, 1173 \mathrm{~K}$, 特よび $1273 \mathrm{~K}$ で行った。 酸化試験では, アセトン脱脂した試験片をアルミナボー 卜にのせ, 所定温度に設定した横型石英管状電気炉に插 入した。試験片は所定の時間酸化した後, 炉冷し, 各種 の分析を行った。一般に, 酸化度の評価には試験片の経 時的重量変化測定が用いられているが, $\mathrm{Ti}_{x} \mathrm{Al}_{y}$ ユーティ ングは試験片の片面のみについて行っていることから, 酸化試験中の重量変化は意味を持たない。したがって, 酸化の進行度は, 所定時間酸化後气の都度断面のEPMA 飞上る酸素特性 $\mathrm{X}$ 線面分布から求まる酸化層厚さで評 


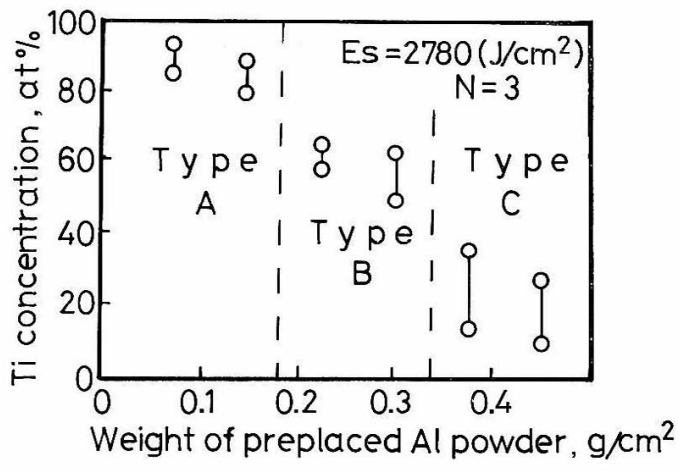

Fig. 2 Relationship between weight of preplaced aluminum powder and titanium concentration in the coating.

価した。その詳細については, 3.2.2 項で述バる。

\section{3. 実 験 結果}

3.1 レーザー溶融反応による $\mathrm{Ti}_{x} A \mathbf{l}_{y}$ のコーティング とコーティング層の特性

Fig. 2 には, Al 粉末塗布量とコーティング層断面の EPMA 分析による $\mathrm{Ti}$ 濃度の関係を示す。 $\mathrm{Ti}_{x} \mathrm{Al}_{y}$ コー ティング層中の $\mathrm{Ti}$ 濃度は, $\mathrm{Al}$ 粉末塗布量に依存し, 表 面の $\mathrm{X}$ 線回折結果から, タイプ $\mathrm{A}$ は $\mathrm{Ti}_{3} \mathrm{Al}$ 単相, タ イプ $\mathrm{B}$ は $\mathrm{TiAl}$ 単相, タイプ $\mathrm{C}$ は $\mathrm{TiAl}_{3}$ と $\mathrm{Al}$ の複 合相であることがわかり，3 種類に大別することができ

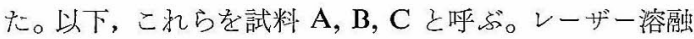
反応では，Al 塗布量とレーザー照射条件を選定するこ

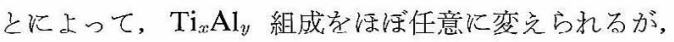
$\mathrm{TiAl}_{3}$ のみのコーティング層を作ることはできなかっ た。な拉，Fig. 2 のタイプA，B，Cの境界は必ずしも 明確ではなく，それらの境界部では複合層になっている ものと考觉られる。また，タイプ BとCの境界の限られ た領域では $\mathrm{TiAl}_{3}$ 単相を作れる可能性はあるが，今回は その研究は行っていない。各試料の SEM 断面字真を Fig. 3 に示すが, 1 回のレーザー照射によって厚さ100 $150 \mu \mathrm{m}$ のューティングを $10 \mathrm{~s}$ 以内に作ることがでさ

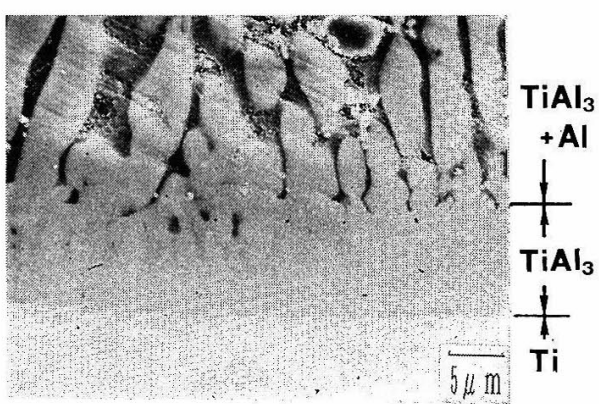

Fig. 4 Transverse section of the coating/substrate interface of Type $\mathrm{C}: \mathrm{TiAl}_{3}+\mathrm{Al}$ composite.

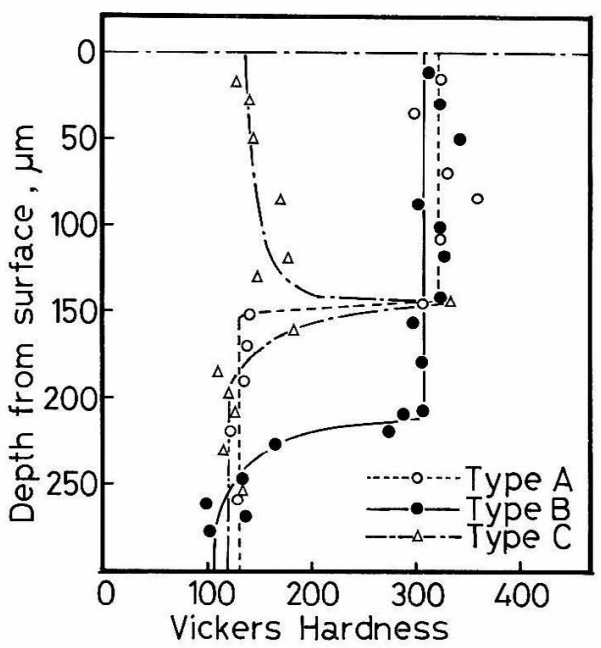

Fig. 5 Vickers hardness profiles of the transverse section of titanium aluminized by the laser fusion reaction.

る。な㸱, 試料 A, B ではそれぞれほぼ $\mathrm{Ti}_{3} \mathrm{Al}$, TiAl 単 相からなる緻密なコーティング層が創成されていたもの の，内部方向には多少の組成変動があるものと考皃た方 がよから。一方, 試料 $\mathrm{C}$ は $\mathrm{TiAl}_{3}$ と $\mathrm{Al}$ からなる緻 密な層状組織になっており，写真の白い部分が金属 $\mathrm{Al}$ である。Fig. 4 は, 試料 C の溶融反応層/基板界面部分
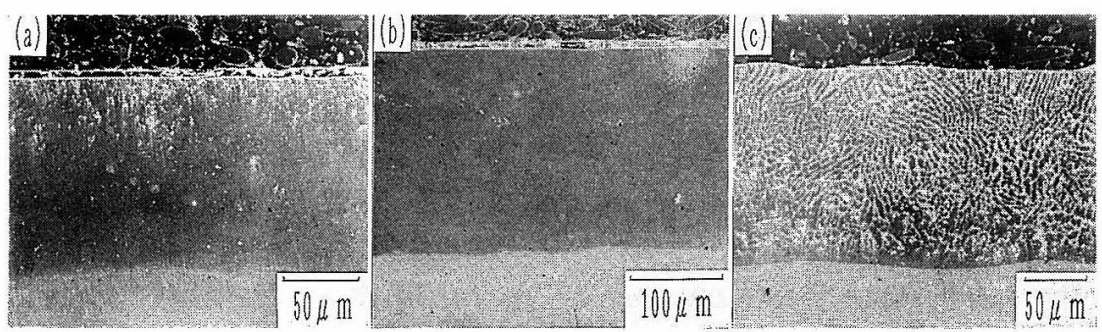

Fig. 3 SEM micrographs of the transverse section of titanium aluminized by the laser fusion reaction.

a) Type A: $\mathrm{Ti}_{3} \mathrm{Al}$, b) Type $\mathrm{B}: \mathrm{TiAl}$, c) Type C: $\mathrm{TiAl}_{3}+\mathrm{Al}$ composite. 


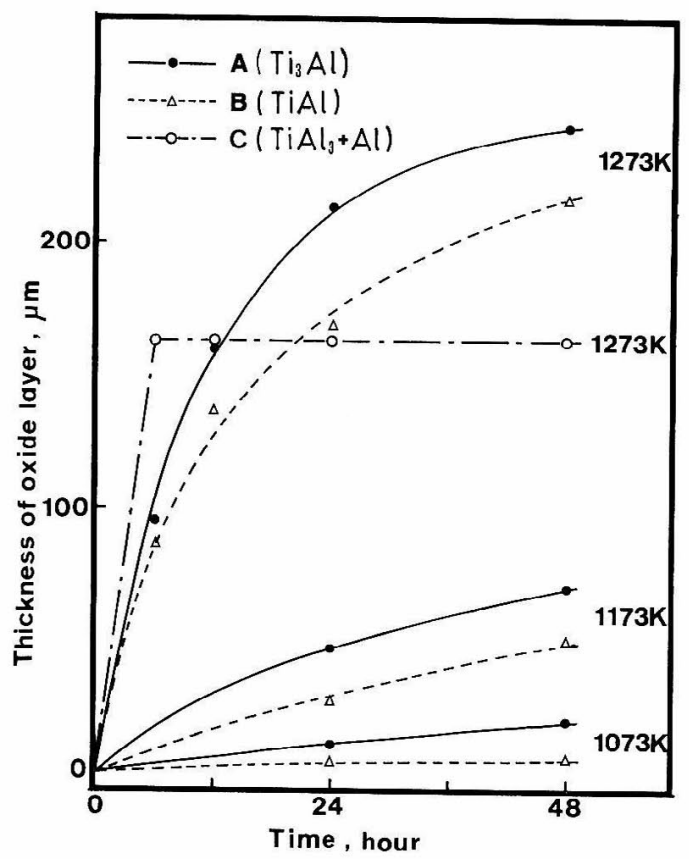

Fig. 6 Effect of temperature on the oxidation of titanium aluminide coating.

の拡大断面写真で, 界面には厚さ $10 \mu \mathrm{m}$ 程度の緸密な $\mathrm{TiAl}_{3}$ 層が形成され，チタン基板を完全に覆っている。 この断面の微小領域 X 線回折 (ビーム径： $30 \mu \mathrm{m}$ ) そ界 面より $10 \mu \mathrm{m}$ 外側の領域について行った結果, 強い $\mathrm{TiAl}_{3}$ の回折ピークと弱い $\mathrm{Al}$, Ti の回折ピークが検出さ れたことから，界面層は $\mathrm{TiAl}_{3}$ 単相であるものと思われ る。

コーティング層断面のビッカース硬度分布を Fig. 5 亿 示す。 $\mathrm{Ti}_{3} \mathrm{Al}$ (試料 $\left.\mathrm{A}\right)$ と $\mathrm{TiAl}$ (試料 $\left.\mathrm{B}\right)$ のコーティング 層の硬度は約 300 320 であったが, $\mathrm{TiAl}_{3}$ と $\mathrm{Al}$ の複 合層（試料 C) では約 120〜165 となった。試料 C の界 面の緻密な $\mathrm{TiAl}_{3}$ 層部の硬度は 330 であることから， $\mathrm{TiAl}_{3}+\mathrm{Al}$ 複合層はかなり金属アルミのリッチな層にな っているものと思われる。

\section{2 高温酸化試験結果}

Fig. 6 には, 試料 A，B，C の各温度に括ける高温酸 化試験後の酸化皮膜厚さと酸化時間の関係を示す。試料 $\mathrm{A}, \mathrm{B}$ の酸化挙動には大きな差は見られないものの, 試 料C住著しく異なった挙動を示した。以下, 試料別に酸 化挙動と酸化機構を述べる。

\subsection{1 試料 $\mathrm{A}\left(\mathrm{Ti}_{3} \mathrm{Al}\right.$ コーティング $)$}

高温に掠ける酸化皮膜厚さが放物線則に従って増加し ていることから， $\mathrm{Ti}_{3} \mathrm{Al}$ コーティングの酸化には酸素の 表面から酸化皮膜を通しての内方搪散が関係しているも のと考觉られる。1073 K に拈いては, 表面に数 $\mu \mathrm{m} の$

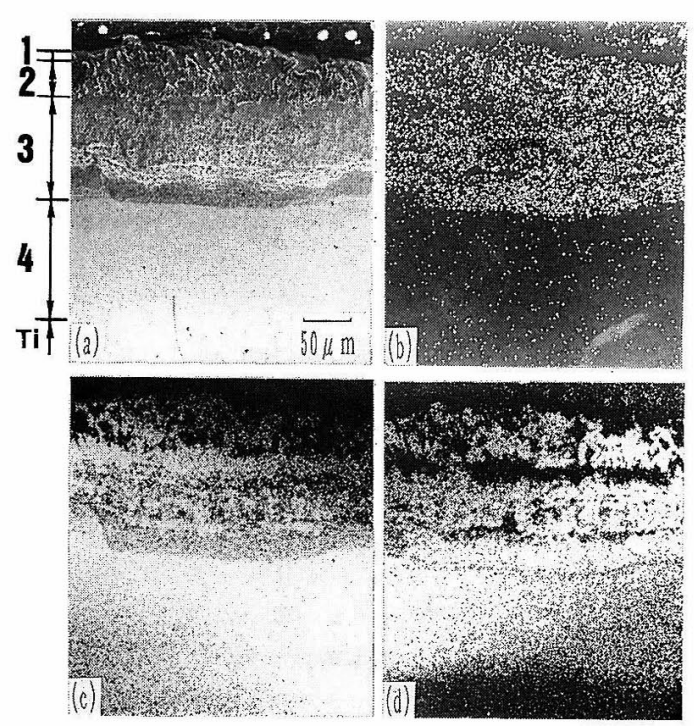

Fig. 7 Transverse section of Type B: TiAl coating after the oxidation test at $1273 \mathrm{~K}$, for $12 \mathrm{~h}$.

a) Secondary electron image, b) Oxygen$\mathrm{K}_{\alpha}$ characteristic X-ray image, c) $\mathrm{T} i-\mathrm{K}_{\alpha}$, d) $\mathrm{Al}-\mathrm{K}_{\alpha}$.

酸化皮膜ができる程度で, 酸化速度は極わて低くなるも のの, $1173 \mathrm{~K}, 1273 \mathrm{~K}$ と温度が上昇するに従って, 酸化 速度子急上昇した。したがって, $\mathrm{Ti}_{3} \mathrm{Al}$ コーティングで は酸素の内方拡散を防ぐことはできず，耐酸化性は期待 できない。なお， $\mathrm{Ti}_{3} \mathrm{Al}$ コーティングの酸化機構につい ては, TiAl コーティングとほぼ同じであるので 3.2.2 項 で述ベることにする。

\subsection{2 試料 B (TiAl コーティング)}

Fig. 6 に示した試料 B の各温度に和り酸化試験の 結果から, TiAl は $1073 \mathrm{~K} て ゙ は$ 極めて優れた耐酸化性を 示すが, $1173 \mathrm{~K}$ 拈よび $1273 \mathrm{~K}$ に打いては耐酸化性が維 持されず，酸化皮膜厚さも増加した。

試料 B の $1273 \mathrm{~K}$ に和ける $12 \mathrm{~h}$ 酸化後のコーティン グ層断面観察と EPMA 面分析を行ったところ, Fig. 7 に示すよらに外側から (1) $\mathrm{TiO}_{2}$ 層 $(7 \mu \mathrm{m}),(2) \mathrm{Al}_{2} \mathrm{O}_{3}$ リ ッチ層 $(36 \mu \mathrm{m})$, (3) $\mathrm{TiO}_{2}+\mathrm{Al}_{2} \mathrm{O}_{3}$ 混合層 $(107 \mu \mathrm{m})$ の順 に形成されていた。 $\mathrm{Al}_{2} \mathrm{O}_{3}$ 層は不連秸的で, $\mathrm{Al}_{2} \mathrm{O}_{3}+\mathrm{TiO}_{2}$ 混合層は多孔質な組織であった。このケースでは, 酸素 $の \mathrm{~K}_{\alpha}$ 特性 $\mathrm{X}$ 線強度が明膫に見られる表層 $150 \mu \mathrm{m}$ を 酸化皮膜としている。また，酸化皮膜/基板界面に $\mathrm{Al}$ の 内方搪散による (4) $\mathrm{Ti}_{3} \mathrm{Al}(120 \mu \mathrm{m})$ 層が生成されていた。 水平方向に見られる䟝離跡は， $\mathrm{Al}_{2} \mathrm{O}_{3}+\mathrm{TiO}_{2}$ 混合層之 $\mathrm{Ti}_{3} \mathrm{Al}$ 層の間に見られた。複雑な酸化皮膜の生成機構は 明らかではないが，既往の論文を参考にしてとのヌカニ

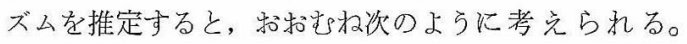



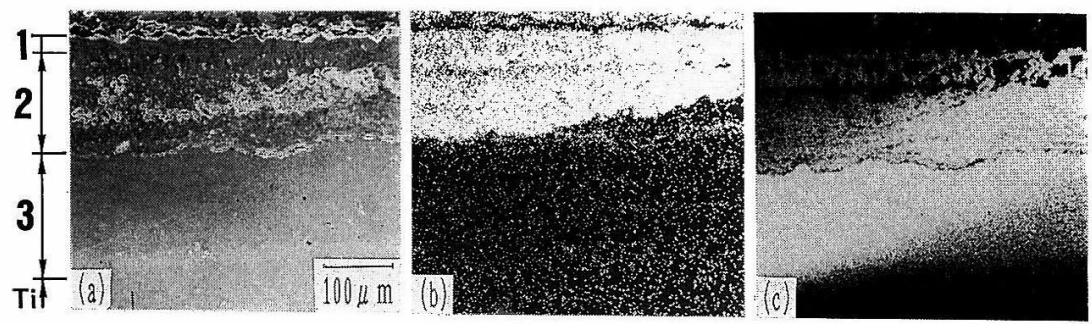

Fig. 8 Transverse section of Type $\mathrm{C}: \mathrm{TiAl}_{3}+\mathrm{Al}$ coating after the oxidation test at $1273 \mathrm{~K}$, for $48 \mathrm{~h}$.

a) Secondary electron image, b) Oxygen- $\mathbf{K}_{\alpha}$ characteristic $X$-ray image, c) $\mathrm{Al}-\mathrm{K}_{\alpha}$.

$\mathrm{TiO}_{2}$ の平衡解離圧は $\mathrm{Al}_{2} \mathrm{O}_{3}$ のそれよりも高い。したが って， TiAl コーティングは酸化によって酸素圧の高い 表面に (1) の $\mathrm{TiO}_{2}$ 層を作る。この層の生成によって酸 化皮膜 $/ \mathrm{Ti}_{3} \mathrm{Al}$ 層界面の酸素濃度が低下し, $\mathrm{Ti}_{8} \mathrm{Al}$ の選択 酸化により (2) $\mathrm{Al}_{2} \mathrm{O}_{3}$ 層ができる。しかし，この $\mathrm{Al}_{2} \mathrm{O}_{3}$ 層は完全に緻密ではなく, 大量の酸素の内方拡散索許し, 酸化が継続する。その結果, (3) $\mathrm{Al}_{2} \mathrm{O}_{3}+\mathrm{TiO}_{2}$ 混合層が生 成されたもの之考光られる。この試験時間内では, 拡散 浸透によって生成した (4) $\mathrm{Ti}_{3} \mathrm{Al}$ 層が見られるが, やが てこの層も酸化しつくされ，酸化皮膜が剝離すると $\mathrm{Ti}$ 基板で激しい酸化が起こるものと考えられる。これらの 結果は，笠原 ${ }^{11)}$, 馬越 ${ }^{12)}$, 鶴見 ${ }^{13)} ら$ 報告と一致してい る。以上のことから， TiAl ユーティング層に， $1173 \mathrm{~K}$ 以上の耐高温酸化能を期待するのは無理であるら。

\subsection{3 試料 $\mathrm{C}\left(\mathrm{TiAl}_{3}+\mathrm{Al}\right.$ 複合コーティング $)$}

$\mathrm{TiAl}_{3}+\mathrm{Al}$ 複合層からなる試料 $\mathrm{C}$ を所定温度に和い て酸化試験を行った結果，Fig. 6 そ示したように 1273 K ש未活る $6 \mathrm{~h}$ の酸化試験後, $160 \mu \mathrm{m}$ 厚の多孔性表面 酸化層を生成するが，その後，酸化皮膜厚さは增加しな かった。Fig. 8 に，1273 K に打ける $48 \mathrm{~h}$ 酸化試験後 の断面の SEM 像写真, 扝よびアルミニウム之酸素の EPMA に上る面分析結果を示す。表面層は (1) $\mathrm{TiO}_{2}$ 》 ッチな $\mathrm{Al}_{2} \mathrm{O}_{3}+\mathrm{TiO}_{2}$ 層, その下に (2) $\mathrm{Al}_{2} \mathrm{O}_{3}$ リッチな $\mathrm{Al}_{2} \mathrm{O}_{3}+\mathrm{TiAl}_{3}$ 層が見られる。(2) 層の厚さは約 $100 \mu \mathrm{m}$ に達する。初期に見られる酸化層の成長は, 複合コーテ ィング層中に存在した $\mathrm{Al} の \mathrm{Al}_{2} \mathrm{O}_{3}$ への酸化にともなう るのである。24h 酸化試験後の表面 X 線回折では, 強 い $\mathrm{TiAl}_{3}$ と $\mathrm{Al}_{2} \mathrm{O}_{3}$, 特よび弱い $\mathrm{TiO}_{2}$ の回折ピークが見 られ，Al の回折ピーク恓められなかった。したがっ $\tau, \mathrm{TiAl}_{3}$ は非常に薄い $\mathrm{Al}_{2} \mathrm{O}_{3}$ 膜を生成するだけで， $\mathrm{TiAl}_{3}$ のほとんどは健全な状態であり， $\mathrm{TiAl}_{3}+\mathrm{Al}$ 複合 層中の $\mathrm{Al}$ 酸化に上って表面近くに $\mathrm{TiO}_{2}+\mathrm{Al}_{2} \mathrm{O}_{3}$, $\mathrm{Al}_{2} \mathrm{O}_{3}+\mathrm{TiAl}_{3}$ 層を生成寸るとと妇に，内方拡散によっ て厚い $\mathrm{TiAl}_{3}$ 層を作る。このように, コーティング層/ 基板界面の繳密で連続な $\mathrm{TiAl}_{3}$ 層によって酸素の内方拡 散が妨げられたものと思われる。コート層/基板界面近傍

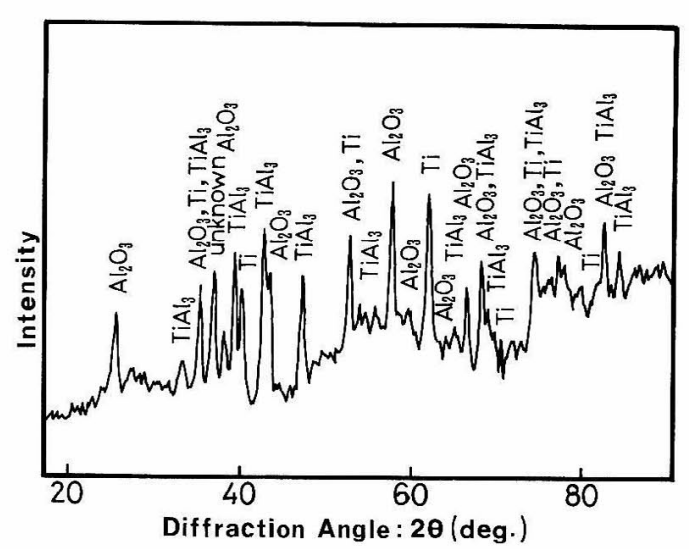

Fig. 9 Micro area X-ray diffraction pattern of type $\mathrm{C}: \mathrm{TiAl}_{3}+\mathrm{Al}$ at coating/substrate interface after the oxidation test at 1273 $\mathrm{K}$, for $48 \mathrm{~h}$.

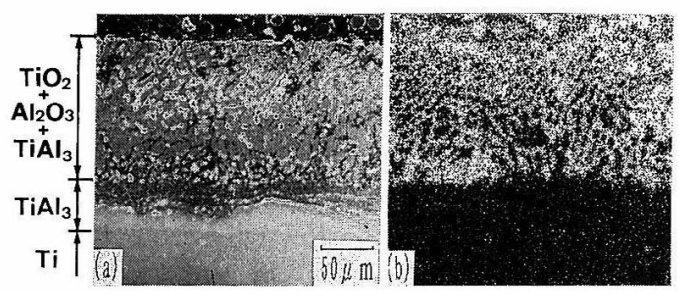

Fig. 10 Transverse section of Type C: $\mathrm{TiAl}_{3}+\mathrm{Al}$ coating after the oxidation test at 1173 $\mathrm{K}$, for $48 \mathrm{~h}$.

a) Secondary electron image, b) Oxygen$\mathrm{K}_{\alpha}$ characteristic $\mathrm{X}$-ray image.

(界面上り外側約 $10 \mu \mathrm{m}$ 火中心を設定) K和ける微小領 域 X 線回折の結果, Fig. 9 に示すように強い $\mathrm{TiAl}_{3}$ と $\mathrm{Al}_{2} \mathrm{O}_{3}$ の回折ピーク扣よび基板 $\mathrm{Ti}$ の回折ピークが検出 された。酸化試験前は $10 \mu \mathrm{m}$ 程度だった緻密な $\mathrm{TiAl}_{3}$ 層 は, 複合コーティング層中に存在した Al の基板への内 方拡散によって新しく $\mathrm{TiAl}_{3}$ 層を生成し, $200 \mu \mathrm{m}$ まで 厚くなったと思われる。Fig. 10 Kは，1173 K に和汁る $48 \mathrm{~h}$ 酸化試検後の䶼化皮膜断面之胘素の EPMA 面分析 
結果を示すが，このときも Fig. 8 と同様な断面構造とな っていることがわかる。このとき， $\mathrm{Al}$ の拡散浸透によっ て新たに $\mathrm{Ti}$ 基板中に生成した $\mathrm{TiAl}_{3}$ 層の厚さは $20 \mu \mathrm{m}$ に達している。

以上のことから, $\mathrm{TiAl}_{3}+\mathrm{Al}$ 複合コーティングの優れ た耐酸化性は，コーティング層中に存在していた $\mathrm{A} 1$ が 1）表層で酸化され $\mathrm{Al}_{2} \mathrm{O}_{3}$ を生成すること，2）基板へ内 方拡散し, 緻密な $\mathrm{TiAl}_{3}$ 層を生成することによるものと 考光られる。 $\mathrm{TiAl}_{3}+\mathrm{Al}$ 複合コーティング層は, 今回の 試験時間内 $(48 \mathrm{~h})$ では初期酸化をらけるのみで, その後 の酸化はほとんど進んでいない。長時間供用に和けるAl の内方拡散にともなら耐酸化性の低下については，今後 さらに長時間の試験を行って評価する予定である。

また，今回の実験では $\mathrm{TiAl}_{3}$ 単相ューティングは行っ ていないが, $\mathrm{TiAl}_{3}$ 単相コーティングを行い, $\mathrm{TiAl}_{3}+\mathrm{Al}$ 複合コーティングの耐酸化性と比較する予定である。

\section{4. 結論}

チタン基板上に塗布したアルミニウム粉末の赤外レー ザー溶融反応を用いるチタンのアルミナイドコーティン グに関する実験を行い，次の結論を得た。

（1）適切な $\mathrm{Al}$ 塗布量とレーザー照射条件を選定す ることにより, $\mathrm{Ti}$ 基板上に $\mathrm{Ti}_{3} \mathrm{Al}, \mathrm{TiAl}$ 単相, および $\mathrm{TiAl}_{3}+\mathrm{Al}$ 複合層の厚膜コーティングが可能である。

(2) $\mathrm{Ti}_{3} \mathrm{Al}$ コーティングは, 酸化速度を低下させる ものの放物線則に従って酸化が進行し，1073 K に括け る酸化を完全に抑制することはできなかった。

(3) TiAl ューティングは, $1073 \mathrm{~K}$ においては優れ た耐高温酸化性を示したが， $1173 \mathrm{~K} ， 1273 \mathrm{~K}$ ではュー ティング層が酸化され，酸化皮膜厚さが放物線則に従っ て増加した。

(4) $\mathrm{TiAl}_{3}+\mathrm{Al}$ 複合コーティングは, 初期酸化によ って $160 \mu \mathrm{m}$ 厚の $\mathrm{Al}_{2} \mathrm{O}_{3}$ リッチな酸化物層が生成すると ともに, $\mathrm{Al}$ の基板方向拡散によって厚い $\mathrm{TiAl}_{3}$ 層が生 成され, $1273 \mathrm{~K}, 48 \mathrm{~h}$ 後においても $\mathrm{TiAl}_{3}$ 層和よび基板 の酸化の進行は阻止された。

（５）レーザー溶融反応は，簡単な雾囲気制御を行ら
のみで，再現性良く，金属間化合物をコーティングする ことができ，金属間化合物形成能を持つチタン基材の高 温強度, 耐高温腐食性の改善に有効であるものと考えら れる。

\section{謝辞}

微小領域 $\mathrm{X}$ 線回折にご協力いただいた日本電子(株) に感謝する。また，本研究に協力した戸張雅彦（現在： 旭硝子 (株)), 増田浩久 (現在: 三菱自動車工業 (株)), 木 村康司, Yrene Longa に感謝する。なお，本研究は池谷 科学技術振興財団の研究助成金を受けて行われた。

(Received December 18, 1991)

\section{文献}

1) D. Shechtman, M. J. Blackburn \& H. A. Lipsitt: Met. Trans., 5, 1373 (1974).

2）吉原美知子, 鈴木徹也, 田中良平：学振耐熱材料 第 123 委研究報告, 31, 75 (1990).

3）小林郁夫, 吉原美知子, 田中良平：学振耐熱材料 第 123 委研究報告, 30, 73 (1989).

4) 武井 厚, 石田 章: 学振耐熱材料第 123 委研究 報告, 31, 529 (1990).

5) 武井 厚, 石田 章, 小野寺秀博, 山崎道夫：金 属表面技術協会第 75 回講演大会要旨集, p. 178 (1988).

6) 辻本得蔵, 竹山雅夫：材料科学, 26, 21 (1989).

7) 間㴊 博, 中山 豊：日本金属学会会報，30，24 (1991).

8) M. Takemoto, M. Tobari \& T. Shinohara: Pro. 6 th Asian Pacific Corrosion Control Conf., c 83 (1989).

9) Y. Hayashi, T. Nanbu \& M. Takemoto: 10 th International Acoustic Emission Symp.: p. 75 (1990).

10）榎並慶英, 竹本幹男：防食技術, 39, 416 (1990).

11）笠原和男, 橋本健紀, 土肥春夫, 辻本得蔵：日本 金属学会誌, 53，58，(1989).

12) Y. Umakoshi, M. Yamaguchi, T. Sakagami \& T. Yamane: J. Materials Science, 24, 1599 (1989).

13）鶴見浩一, 日野春樹, 藤岡順三, 西山幸夫：学振 耐熱材料第 123 委研究報告, 29, 77 (1988). 